\title{
Universiteit
}

Leiden

The Netherlands

\section{Households and communities in the central Anatolian Neolithic}

Düring, B.S.; Marciniak, A.

\section{Citation}

Düring, B. S., \& Marciniak, A. (2005). Households and communities in the central Anatolian Neolithic. Archaeological Dialogues, 12(2), 165-187. Retrieved from https://hdl.handle.net/1887/14169

Version: $\quad$ Not Applicable (or Unknown)

License: $\quad$ Leiden University Non-exclusive license

Downloaded from: $\quad$ https://hdl.handle.net/1887/14169

Note: To cite this publication please use the final published version (if applicable). 


\title{
note
}

Archaeological Dialogues 12 (2) 165-187 (C) 2006 Cambridge University Press

doi:10.1017/S138020380600170X Printed in the United Kingdom

\section{Households and communities in the central Anatolian Neolithic} Bleda S. Düring and Arkadiusz Marciniak

\begin{abstract}
The neolithic communities of central Anatolia are generally reconstructed as being constituted by relatively autonomous and homologous households occupying discrete residences and performing most domestic activities in the house. In this reconstruction households are seen as the uniform and unproblematic basic component of society. This paper aims to problematize this modular conception of central Anatolian Neolithic societies, and wants to draw attention to the multiple forms in which households occurred and the manner in which they were embedded in larger social associations. It is argued that different levels of social association can only be understood in relation to each other. Further, the manner in which social configurations in central Anatolia changed over time is explored. This will be done by presenting evidence from two central Anatolian Neolithic sites: Aşıkı Höyük and Çatalhöyük. In particular, we argue that households became autonomous and clearly bounded entities only towards the end of the central Anatolian Neolithic, and that too little consideration has been given to the neighbourhood and the local community encompassing individual households.
\end{abstract}

\section{Keywords}

Neolithic society; domestic buildings; households; neighbourhoods; local communities; central Anatolian Neolithic

\section{Introduction}

In this paper we will argue that Near Eastern Neolithic societies in general, and those of central Anatolia in particular, are too often interpreted from a household-centred perspective based on contemporary preconceptions that are generally not scrutinized. Instead, we want to bring to the fore the complexity of social configurations in this period by focusing on evidence from the central Anatolian Neolithic. We aim to demonstrate that the local communities of this cultural horizon were constituted at various levels, including those of the household, the neighbourhood and the local community. Our broader purpose is to problematize some of the general models of Neolithic society current in Near Eastern archaeology, and to argue that more regionally focused studies and a broader palette of social concepts 
are needed in order to understand Neolithic societies adequately. This paper presents a first attempt in that direction.

The study of the central Anatolian Neolithic is influenced in many respects by the more developed research that has taken place in the Levant, and to a lesser degree that in Europe, where investigations have been both more intensive and more interpretative than in central Anatolia. Accordingly, we will briefly discuss a number of reconstructions of Neolithic societies relating to the Levant, in order to contextualize interpretative work on social formations in central Anatolia. Following that we will outline our understanding of the relation between households and communities. Subsequently, the settlement evidence from the central Anatolian Neolithic sites of Aşıklı Höyük and Çatalhöyük will be discussed in detail as well as the manner in which the settlement fabric at these sites was crucial to the constitution and reproduction of society. On the basis of that discussion, some of the social transformations that occurred in the central Anatolian Neolithic will be presented. In particular, it is argued that households in the studied region became well-defined and autonomous entities only towards the end of the period. It is further argued that the earlier Neolithic in this region is characterized by the predominance of neighbourhood communities in the constitution of local communities. Finally, we will discuss some of the implications of our understanding of this regional trajectory of development for how we perceive the Neolithic of central Anatolia.

\section{Household and community in the study of the Near Eastern Neolithic}

The dominant view of Neolithic societies in the study of the Near Eastern Neolithic in general, and in central Anatolia in particular, has been one in which communities were composed of relatively autonomous households that were held together by institutions binding the local community as a whole. Accordingly, households have often been considered as the relatively unproblematic and uniform basis of society, and little attention has been devoted to social associations intermediate between households and the local community.

This view of Neolithic society can be traced back to a highly influential paper by Flannery (1972; see also Flannery 2002) in which he discussed the social and economic changes that accompanied the shift from mobile huntergatherer communities to more sedentary and larger social groups during the Neolithic transition in the Levant. In Flannery's model the emergence of economically autonomous households managing their own food production and consumption was of crucial importance in the processes of intensification that were at the root of the formation and the reproduction of the Neolithic economy (Flannery 1972, 48). These households were equated with family groups and a gendered division of labour and space within the house (Flannery 1972, 39-40). Further, Flannery argued that these households were held together in larger communities by sodalities linking members of different households and by communal labour tasks, ceremonies, parties and so on (Flannery 1972, 30-40; Flannery 2002). We will label this conceptualization of Neolithic communities and the central role that economically self-sufficient households play therein 'the modular-household model'. 
This model has been of great influence in later studies on Neolithic societies in the Levant, and Flannery's interpretations are reflected in the work of many prominent archaeologists (Netting 1990, 39; Byrd 2000; Hole 2000, 205; Watkins 2001, 497; Banning 2003, 14). The transformations of the ways in which societies were constituted in the Levantine Neolithic has been most explicitly studied in this framework by Byrd (1994; 2000), who argues that two related developments took place: first, the emergence of smaller social networks for sharing production and consumption activities; and, second, the creation of more formal and institutionalized mechanisms for community integration. In this model the adoption of agriculture is associated with the development of private property where each household produced, stored and consumed its own crops. To us Byrd's reconstructions appear similar in many respects to those proposed earlier by Flannery. ${ }^{1}$

In the context of the central Anatolian Neolithic only a few studies have dealt explicitly with the constitution of society and the role of households therein at sites such as Aşıklı Höyük, Canhasan III, and Çatalhöyük, but in many other studies households surface implicitly as the accepted basis of communal life (Yakar 1991, 295; Esin 1996, 38-39; Acar 2001, 16).

A more explicit discussion of households can be found in three articles dealing with the central Anatolian Neolithic. First, writing on Çatalhöyük, Hodder $(1996,47)$ states, 'Each household seems to have been relatively selfsufficient in terms of production, tool manufacture and maintenance', and he further stresses an ideology of continuity of individual households that he argues dominates much of the patterning at the site (ibid.; cf. Hodder 2005, 23).

Second, Conolly (1999) has argued also for Çatalhöyük that, for the most part, 'Çatalhöyük's socio-economic and productive activities appear to be organized around the individual household' $(1999,798)$. These households are held to have been more or less autonomous entities in the early levels XVIB at the site. For the upper levels VIA-I it is argued that lithic production increasingly became a specialized activity practised in some households only, and that households became more interdependent, although it is posited that this may well have stayed within the productive sphere of the kin group (Conolly 1999, 798-99).

Third, Steadman (2000) argues that at Canhasan III houses were uniform and used for a limited range of purposes, but that they were used for a wider set of activities at Çatalhöyük, on the basis of the presence of a greater diversity of features in the buildings, and a more pronounced subdivision of space $(2000,177,182$; cf. Hodder 2005, 23). In this reconstruction households are envisaged as autonomous modular entities, and no attention is given to the fact that the domestic buildings at both Canhasan III and Çatalhöyük are embedded in larger blocks of buildings.

What we will argue is that the reconstruction of Neolithic society in central Anatolia as constituted by autonomous households can be only partially substantiated by the archaeological evidence and that too little attention has been given to the ways in which households were embedded in larger social associations. Accordingly we argue that the view of central Anatolian Neolithic communities as being constituted by relatively 
autonomous modular households needs to be challenged. In the following section we will show that the domestic sphere can take on many forms and need not comply with the modular-household model.

\section{Relating households and communities}

The household literature is vast (recent studies include Blanton 1994; Allison 1999; Robin 2003). Households are commonly defined on the basis of a combination of shared residence at the house level and the pooling of economic resources. For instance, Wilk and Rathje (1982, 618) define households as binding the production, distribution, transmission and reproduction of a group of co-residents. From studies of recent households in a variety of settings it has become clear that residence and the pooling of economic resources do not necessarily overlap (Wilk and Rathje 1982, 62021; Allison 1999, 4-5; Byrd 2000, 66). In relation to these two elements, some archaeologists have argued that the focus of household studies should be on the reconstruction of activity areas and activity groups on the basis of artefact and feature distributions and micro-residues in order to reconstruct economic pooling (Ashmore and Wilk 1988, 4-5, Allison 1999, 5), while others have argued that a household concept centred on co-residence is more useful to archaeology (Blanton 1994, 5; Hendon 1996, 47).

We adopt a broad understanding of households ranging from autonomous and clearly bounded households residing in discrete buildings with evidence of most domestic and some craft activities performed within the residence, as manifested in the presence of special-purpose activity areas and features in buildings, on the one hand, to households dispersed over disconnected spaces executing their domestic activities in locales not exclusively associated with any particular household, on the other. The sorts of household present in any particular cultural setting should be determined on the basis of a contextualized assessment of the buildings and their inventories, rather than being assumed on an a-priori basis (Wilk and Rathje 1982, 620; Byrd 2000, 66-67).

An important component of this perspective is that households cannot be studied in isolation, but need to be contextualized within their wider social setting. The ways in which households are connected to and embedded in society are both diverse and culturally specific (Spencer-Wood 1999, 173-77; Robin 2003, 330-34). To exemplify this variability we will briefly present two ethnographical cases that we believe to be particularly significant for understanding the households of the central Anatolian Neolithic.

The first example is drawn from the Moroccan town of Sefrou described by Geertz (1979). There, a large number of families, not all of them kin, inhabit the 'dar', a multi-family residence. In Geertz's (1979, 323) words, 'In Moroccan eyes, the dar has a social integrity of greater significance than the room (the bit), despite the fact that each room serves as the place of orientation of a woman, her husband, and their children.' Thus, in the case of Sefrou, it is the dar that is the main constituent unit in society rather than the household.

A second example, that of the Dogon in Mali described by Lane (1994), highlights the variability in the relations of household groups to the building 
that they occupy. In this case individual lineages own a number of houses dispersed across the village, which appear similar with regard to their organization of space and composition of features. The social significance of these buildings differs, however. Some houses are inhabited by couples with their offspring, others by adolescent boys and unmarried men, while a third group of buildings is occupied by widowed women and unmarried girls. When the status of a person alters he or she will normally move to another house rather than remain in the house of residence. Thus houses in this village are not tied up with the fortunes of individual households, but are distributed amongst the members of the lineage. Consequently, these houses are not modified according to the changing demands of their inhabitants and therefore show little alterations except for ongoing processes of decay and maintenance.

On the basis of such examples it is clear that households can take on many forms and are nested elements in larger social configurations of various kinds, including, for instance, the lineage, the neighbourhood and the local community. It is argued that Neolithic societies can only be understood adequately from a holistic perspective in which specific forms of social association, such as households, should be analysed in the context of the social configuration of which they are part (Kovacik 2002, 52-53).

In the following paragraphs we will explore the evidence from two main sites of the central Anatolian Neolithic: Aşıklı Höyük and Çatalhöyük, with these considerations in mind. In particular, we will focus on the relations between households and the neighbourhoods in which they are located. Further, these interrelations will be approached diachronically in order to outline the manner in which the fabric of Neolithic societies in central Anatolia was transformed over time. We argue that the sequence in central Anatolia is best understood as a regional trajectory in which settlements and societies took on idiosyncratic forms, in which symbolism, notions about social life, memorized traditions and practical considerations interlinked in a specific configuration early in the central Anatolian Neolithic, and that subsequent developments occurred on the basis of this particular arrangement of elements.

\section{The settlements of the central Anatolian Neolithic}

The central Anatolian Neolithic can be dated between $c a 8500$ and 6000 Cal. B.C. Central Anatolia refers to the Anatolian Plateau, but here a much smaller area is considered in the south of this region (see figure 1). Only a handful of sites that can be dated to the Neolithic have been excavated in this region (for an overview see Gérard and Thissen 2002), but nonetheless it has become clear that the Neolithic of central Anatolia differs in such matters as settlement form, burial customs and chipped stone industries from that of the Fertile Crescent (Özdoğan 1999, 229-32; Özbaşaran 2000, 135; Balkan-Atlı and Binder 2001, 194), despite the existence of frequent interaction between the two regions, manifested in the occurrence of Cappadocian obsidian in the Fertile Crescent and the adoption of domestic plants in the reverse direction (Colledge, Conolly and Shennan 2004). 


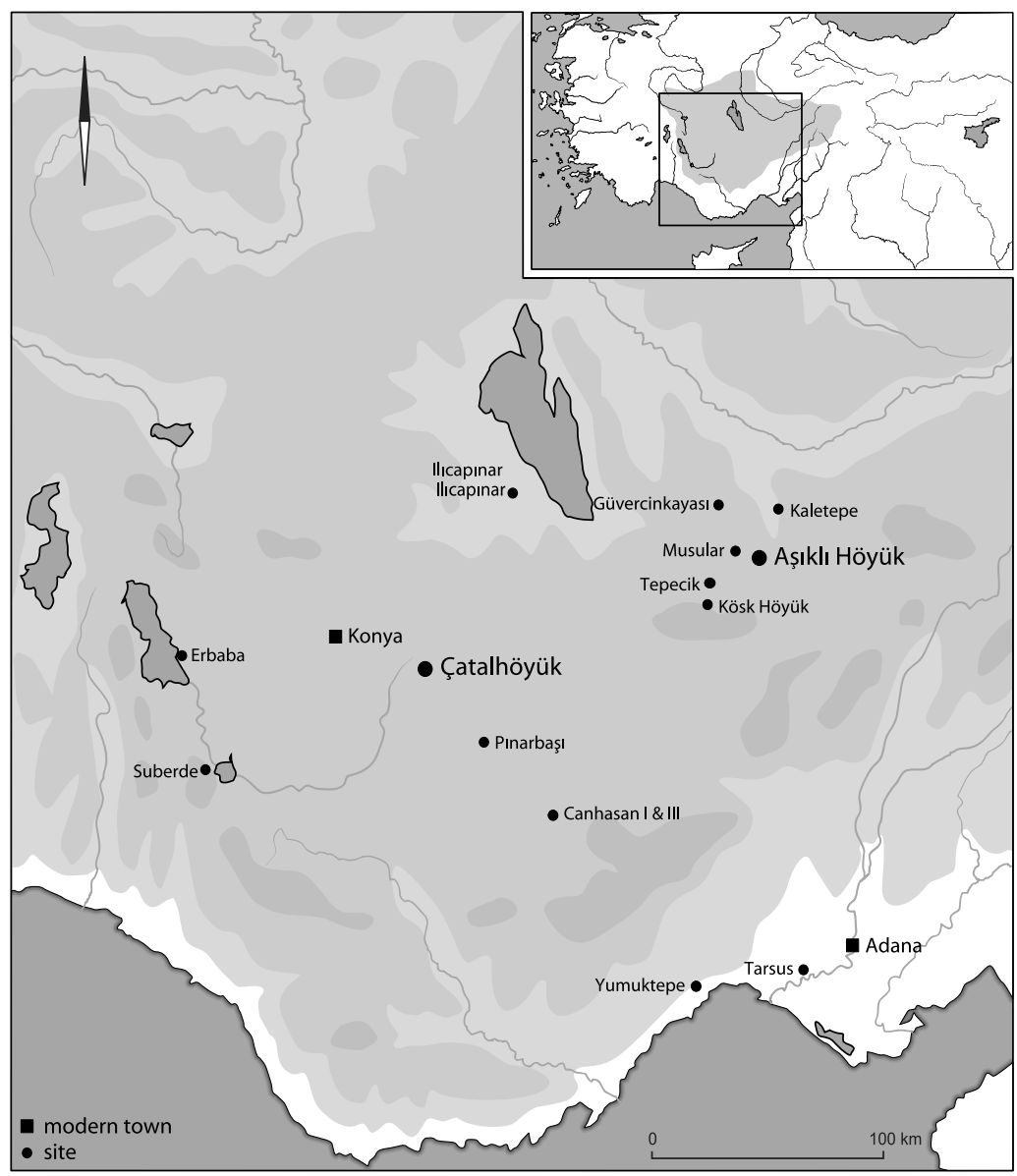

Figure 1 Map of central Anatolia showing the most important Neolithic sites; the two main sites discussed in this paper are indicated in bolder letters. Figure prepared by M. Oberendorff.

One feature so far unique to the central Anatolian Neolithic is the phenomenon of the clustered neighbourhood settlements (Özbaşaran 2000, 135). In these settlements individual buildings are typically constructed directly adjacent to one another in neighbourhood clusters of approximately 30 to 40 buildings. These will normally be separated from one another by streets, alleys and midden areas, and additional midden areas may be located within the neighbourhood clusters. The individual buildings in these neighbourhoods were accessed from the roof by way of a ladder, as has been demonstrated by the find of plaster scars in the former location of the ladder and the find of charred ladder bases (Mellaart 1963, plate 16-b).

This type of settlement is alien to modern society, in which public space borders on almost all buildings, and suggests that we might be dealing with a very different sort of social fabric related to this peculiar settlement type. In the following we will explore the manner in which the central Anatolian Neolithic 
settlements were constituted and discuss temporal changes in their spatial organization using contextual evidence and room sizes. More specifically we will try to distinguish possible household units and investigate how these are embedded in the fabric of the surrounding neighbourhood. In this manner we hope to throw new light on the question of in what manner households were interwoven with larger social collectivities in the central Anatolian Neolithic.

\section{Aşıklı Höyük}

The site of Aşıklı Höyük is located on the banks of the Melendiz river at the western fringe of Cappadocia. The four-hectare site was first discovered in the 1960s and has been excavated by Istanbul University from 1989 onwards (Esin et al. 1991; Esin and Harmankaya 1999). Some 47 radiocarbon samples have securely dated the site to $c a$ 8200-7400 Cal. B.C. (Esin 1998). The site can be placed in the Aceramic Neolithic in the local culture-historical sequence.

The main focus of the excavations at the site has been the exploration of large horizontal exposures at the summit of the mound, totalling some $4000 \mathrm{~m}^{2}$. These exposures provide an important window into the building traditions and the spatial organization of the settlement. Four different types of space have been discovered to date (figure 2). First, there is a wide street measuring some four metres in diameter and paved with stones that forks near the eastern edge of the excavations (GA, SK). Due south of this paved street one of the most remarkable discoveries made at the site has been that of a large monumental complex surrounding the large court HV, which differs from the other buildings at the site in scale, building materials and building technologies.

In the northern part of the excavations at Aş1klı Höyük a large open midden area (JA) was found. This contained deposits of domestic refuse such as burnt animal bones and botanical remains, but also waste from bone processing and chipped stone tool industries. From this we can infer that the area probably served a number of activities including tool production, food preparation and consumption (Esin and Harmankaya 1999, 125).

Finally, interspersed between the large midden and the paved streets a large number of small and tightly clustered loam buildings were found. Each building was surrounded by a separate set of walls despite the fact that the structures were often constructed directly adjacent to one another. From calculations on the load-bearing capacity of the walls, it is clear that these buildings could not have had an upper storey (Esin et al. 1991, 153). Some of the rooms contain hearths or bins, but these are not ubiquitous. In addition, some of the spaces had sub-floor burials. Although internal doors facilitating traffic between the rooms of buildings were found, external doors are completely absent. Given this circumstance it seems probable that buildings were accessed from the roof level.

The loam buildings of Aşıklı Höyük appear to be organized into a number of tightly nucleated neighbourhoods that are separated by streets or alleys. The number of rooms within each neighbourhood was somewhere in the range of 60 , and these were part of an estimated 30 to 40 buildings (see 


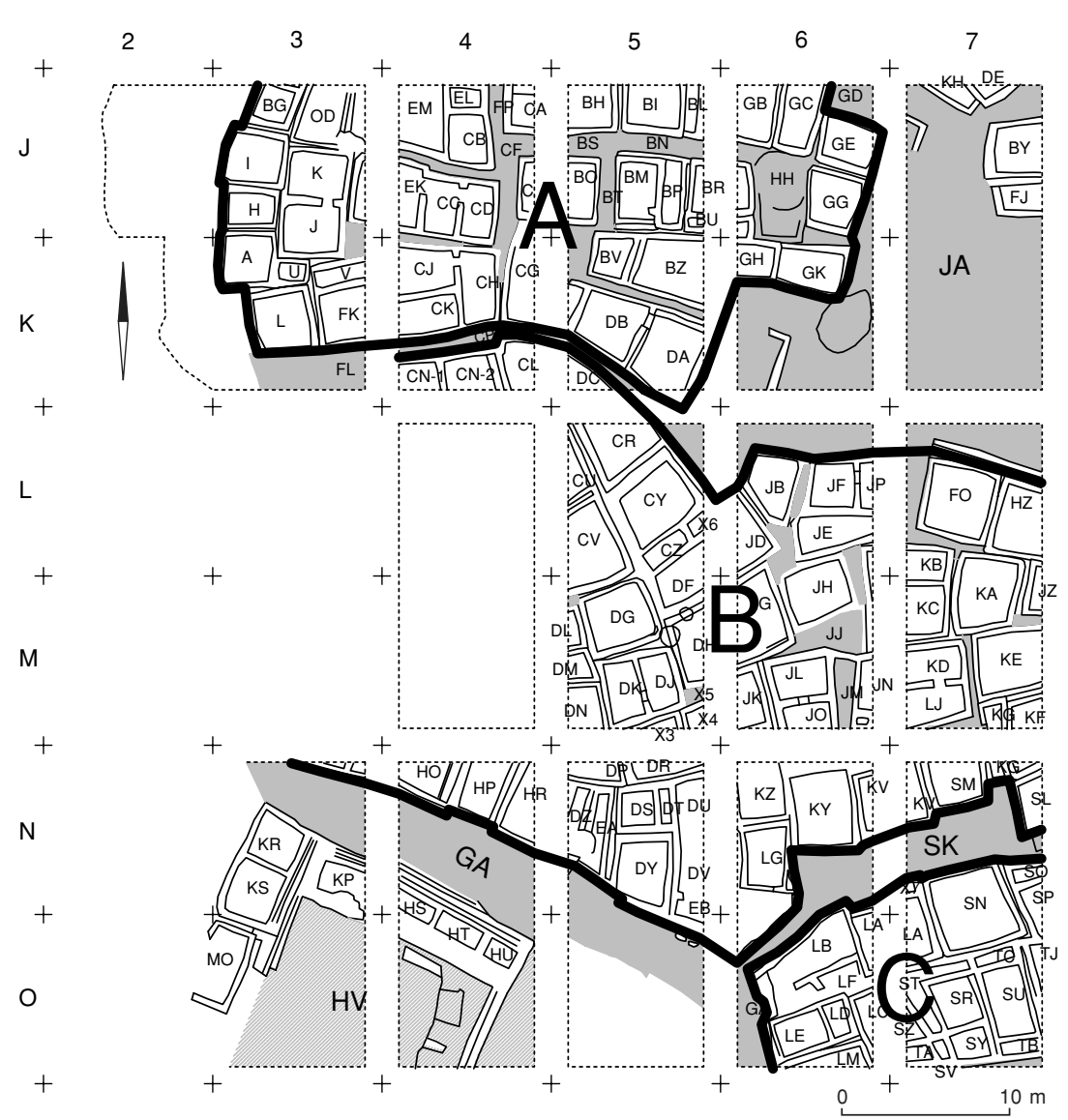

Figure 2 Tentative distinction of clustered neighbourhoods at Aşıklı Höyük (excavated exposure is larger). Based on figure 3 in Esin and Harmankaya (1999). Figure prepared by M. Oberendorff.

figure 2). Within these neighbourhoods most of the traffic seems to have taken place on the roofs.

One of the questions that come to mind when exploring these neighbourhoods is in what manner the individual rooms and buildings embedded in these clusters might have been associated with households. A first element that we can look at is the size of the rooms and buildings. The rooms at Aşıklı Höyük are of a restricted size range, with an average of about $6.5 \mathrm{~m}^{2}$, and $80 \%$ are smaller than $12 \mathrm{~m}^{2}$ (see figure 3 ). Some buildings have only a single room (the average interior size of these buildings is $9 \mathrm{~m}^{2}$ ), while others are composed of multiple rooms (the average interior size of which is $12 \mathrm{~m}^{2}$ ). These sizes are surprisingly small. Although cross-cultural comparisons in which floor surfaces are specified per person (Naroll 1962; Cook and Heizer 1968; Casselberry 1974) are no longer considered valid, these formulae may serve to provide a first idea of how many people could have lived in these rooms and buildings. According to these estimates the average buildings at Aşıklı Höyük, with sizes of between 9 and $12 \mathrm{~m}^{2}$, could have been inhabited 


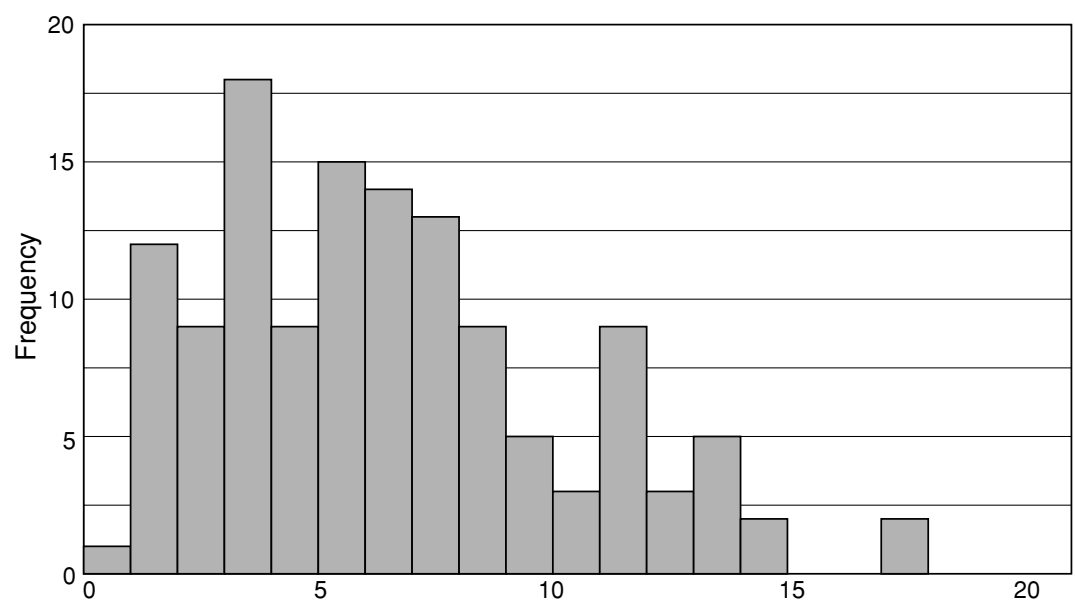

Figure 3 Interior room sizes of Aşıkı Höyük in $\mathrm{m}^{2}(n=129)$. Based on measurements of the digitized reproduction of Figure 3 in Esin and Harmankaya (1999). Figure prepared by M. Oberendorff.

by one to five people. We would argue that not much can be based on these estimates, but that these figures do seem to suggest that many of the buildings at Aşıklı Höyük are perhaps too small to have served as household residences. However, estimates like this are problematic because population densities of rooms can vary dramatically, not only from one culture to the next but even within a single settlement (Dohm 1990, 204; Horne 1994, 159). For this reason we now want to turn to the features found within the buildings at Aşıklı Höyük, in order to investigate what these may tell us about the activities that took place in these buildings.

In particular we want to focus on the distribution of the hearths at Aşıklı Höyük. These are highly distinctive features. Hearths were usually constructed in one of the corners of the rooms, where a small rectangular depression dressed with flat pebbles was created. Along the edges larger stones of a suitable flat shape were used to create an upright edge that was generally no more than $20 \mathrm{~cm}$ above the level of the floor. On the short side of the rectangular hearths this upright edge is missing, and it was here that the fire mouth was located. It is also in this area that concentrations of ash were most often found. The pebbles along the edges of the hearth and those on its floor seem to have been covered by a thin plaster layer (Özbaşaran 1998). The hearths of Aşıklı Höyük appear on the plans and have been published in some detail (ibid.), which makes it possible to study their distribution across the settlement (see figure 4). Remarkably, only about $30 \%$ of the rooms excavated at Aşıklı Höyük contained a hearth (ibid.). The distribution of these hearths over the settlement does not seem to be clearly patterned, and it is not possible to discern clusters of rooms centred on a room with a hearth.

We would argue that, had households been autonomous units, every building should at least have had one hearth at Aşıklı Höyük. The fact that we cannot discern spatial clusters of rooms centred on a room with a hearth 


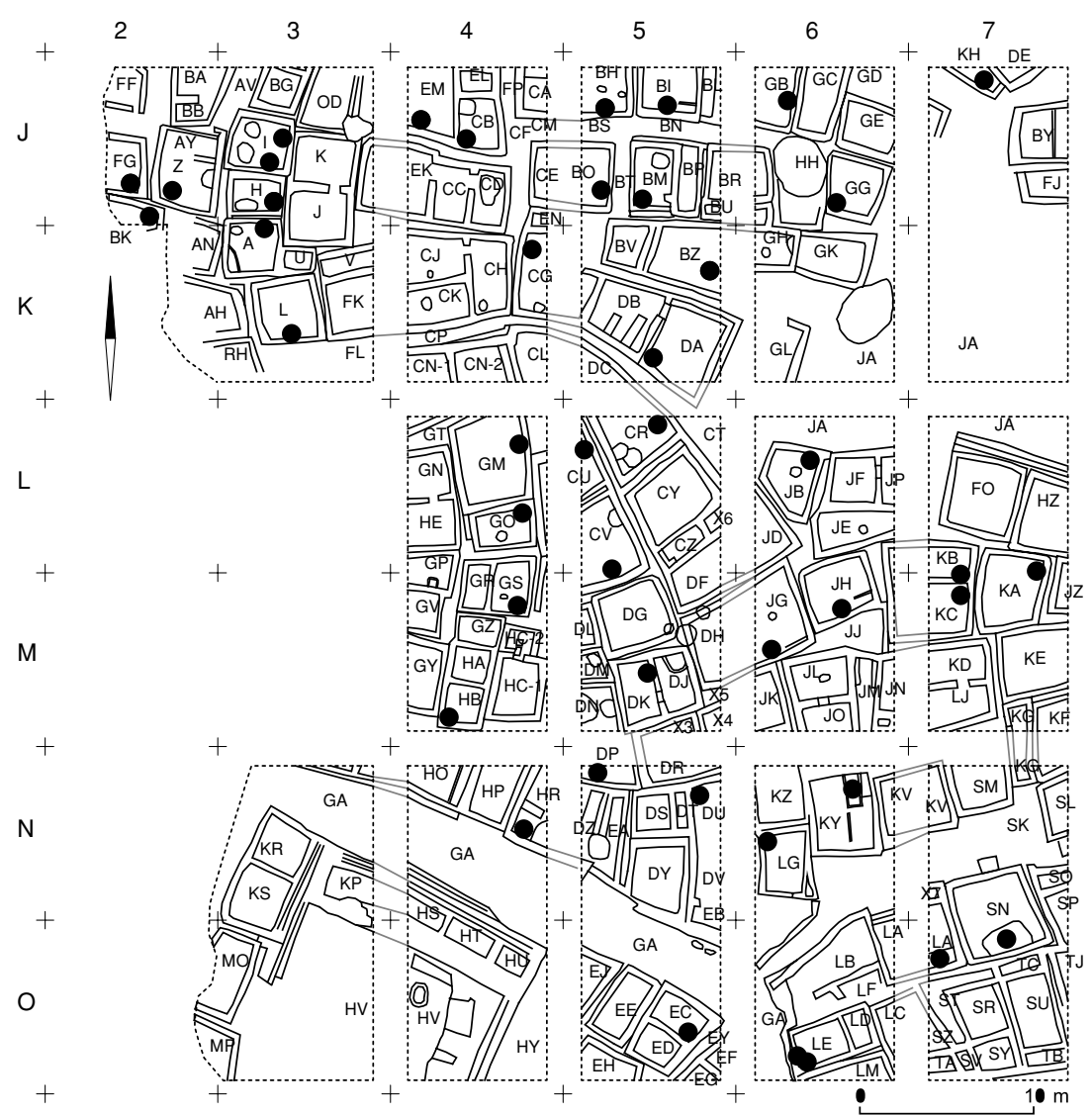

Figure 4 Distribution of hearths (dots) over part of the Aşıklı Höyük settlement. Based on information in Özbaşaran (1998). Figure prepared by M. Oberendorff.

suggests that households were not clearly bounded entities occupying discrete buildings in which most domestic and craft activities were performed. Instead, households were probably spread across the neighbourhood in a pattern no longer discernible to us, and most likely performed many of their domestic activities in communal open areas such as JA.

Relating Aşıklı Höyük households to the two criteria on the basis of which households have been defined - residence and economic pooling it seems to us that the households at Aşıklı Höyük were clearly bounded neither in terms of residence nor in terms of separate activity areas. This does not necessarily imply that households were not important to social life at Aşıklı Höyük; potentially they could have been more or less exclusive entities occupying a number of rooms dispersed across the neighbourhood and could have performed most cooking and processing in communal open areas on a household basis. However, households were not autonomous in a manner that makes it possible to define them archaeologically. 
In light of these considerations, we would suggest that it is probably more appropriate to regard the Aşıklı Höyük neighbourhood clusters as belonging to a neighbourhood community sharing a number of facilities and resources. Within these neighbourhoods would have lived a large number of families who probably did not run autonomous households. It is likely that these neighbourhood communities were key elements in the constitution of society at Aşıklı Höyük.

Another element that could point to the neighbourhood as the major social entity at Aşıklı Höyük is constituted by the sub-floor burials. In total only 70 of these were found in the approximately 400 rooms excavated at the site (Esin and Harmankaya 1999, 126), indicating that only a small selection of the dead were interred in the settlement. This may indicate that the deceased were interred as part of the ceremonies of larger social collectivities as opposed to those centred on the household. This seems to be another indication of the significance of communal forms of social association in this Early Neolithic horizon.

Two further issues should be considered here. First, the particular type of spatial organization of the settlement at Aşıklı Höyük did not develop by accident. People must have had a culturally determined preference to live in neighbourhood clusters, and this does not seem to accord with a conception of society in which the autonomous household is given pride of place.

Second, the buildings at Aşıklı Höyük were not well suited to modifications to adjust them to the changing demands of their inhabitants. In most cases, extra rooms cannot be added to the buildings. Further, in a diachronic perspective buildings at Aşıklı Höyük reveal a remarkable building continuity (Hodder 1998; Düring 2005). This building continuity practised at Aşıklı Höyük suggests a system in which buildings were not privately owned, in which case we would expect them to be modified on a regular basis, but one in which the rooms were distributed amongst the community members according to their changing needs and statuses. We can envisage people moving from one building to the next, or being assigned extra rooms, rather than adapting buildings to their needs (cf. Lane 1994).

Given these circumstances (the impossibility of defining discrete spatial clusters of rooms that might have belonged to households, a preference for living in neighbourhood clusters and the fact that people probably did not own buildings), we suggest that the modular-household model does not fit the evidence at Aşıklı Höyük and that attempts to distinguish such units amount to superimposing an alien concept on the data at hand. We will now turn our attention to our second case study, Çatalhöyük, where society and settlement seem to have been configured in a different, although in many ways related, manner.

\section{Çatalhöyük}

The site of Çatalhöyük is located on the Konya Plain and was placed along the former course of the Çarşamba river. The site was first excavated between 1961 and 1965 by the British archaeologist James Mellaart. Despite the relatively short duration of these initial excavations the results 
were spectacular, and the site quickly became one of the most famous in archaeology. From 1993 onwards archaeologists from a variety of countries, including teams from Greece, Poland, the United Kingdom, the United States and Turkey, are once more investigating this key site, under the direction of Ian Hodder. To date 13 building horizons have been excavated at Çatalhöyük, labelled levels XII to I. This sequence is now preceded by an off-site sequence 'pre-level XII.E-A' (Farid forthcoming). The sequence as a whole can be dated to approximately 7400-6000 Cal. B.C. (Cessford 2001; Czerniak and Marciniak 2004). In culture-historical terms the pre-level XII.E-A sequence, which can be dated to 7400-7000 Cal. B.C., can be assigned to the Aceramic Neolithic, levels XII-VI can be dated to between 7000 and 6600 Cal. B.C., and belong to the Early Ceramic Neolithic, whereas levels V-I, dated to 6600-6000 Cal. B.C., fall in the Late Ceramic Neolithic period.

A major shift seems to have occurred at Çatalhöyük in the transition from level VI to level V, although the break may not be as sharp as initially suggested (Düring 2001; 2002). These changes occur in lithic industries (Conolly 1999), the typology and gender of figurines (Hamilton 1996, 225; Voigt 2000, 287), ceramic traditions (Mellaart 1966, 170; Last 1996, 118), wall paintings (Mellaart 1967, table 13; Voigt 2000, 287), moulded features and installations (Todd 1976, 50), and architectural traditions (Düring 2001).

In the early building levels XII-VI at Çatalhöyük the buildings that have been found are in many ways similar to those of Aşıklı Höyük. The structures were built of loam and clustered in streetless neighbourhoods, which were separated from each other by alleys and courtyards. Each neighbourhood cluster consisted of about 30 buildings (see figure 5), which were accessed from the roof level. External doors seem to be completely absent, and many ladder imprints have been found in the wall plaster at the site. A further parallel to Aşıklı Höyük is that buildings have a great degree of continuity, being rebuilt on the same location and with the same proportions and interior arrangements for up to six building levels and over several hundreds of years (Düring 2005).

In these early levels at Çatalhöyük we can, in contrast to Aşıklı Höyük, distinguish clearly defined living rooms and modular household units in the clustered neighbourhoods. To substantiate this point we will again consider both room sizes and the distribution of features within individual rooms. At Çatalhöyük there is a common category of rooms that can be positively identified as living rooms containing a range of more or less standard features (Mellaart 1967, 61, figure 11). In the southern part of these rooms one will often find the fire installations, consisting of square free-standing hearths and oval domed ovens built adjacent to the walls. In the same area is generally located the ladder entrance, and it seems plausible that the ladder access also acted as a chimney. This southern area often contains relatively large amounts of micro-debris, consisting of charcoal, obsidian chips and small bone fragments (Hodder and Cessford 2004, 26-28). It can be opposed to the platforms in the north-east of the living rooms, which were much cleaner and seem to have been plastered more frequently. This cleaner area is also where the intramural sub-floor burials are most often found, and where the wall paintings and mouldings are often located that have made the site famous. 


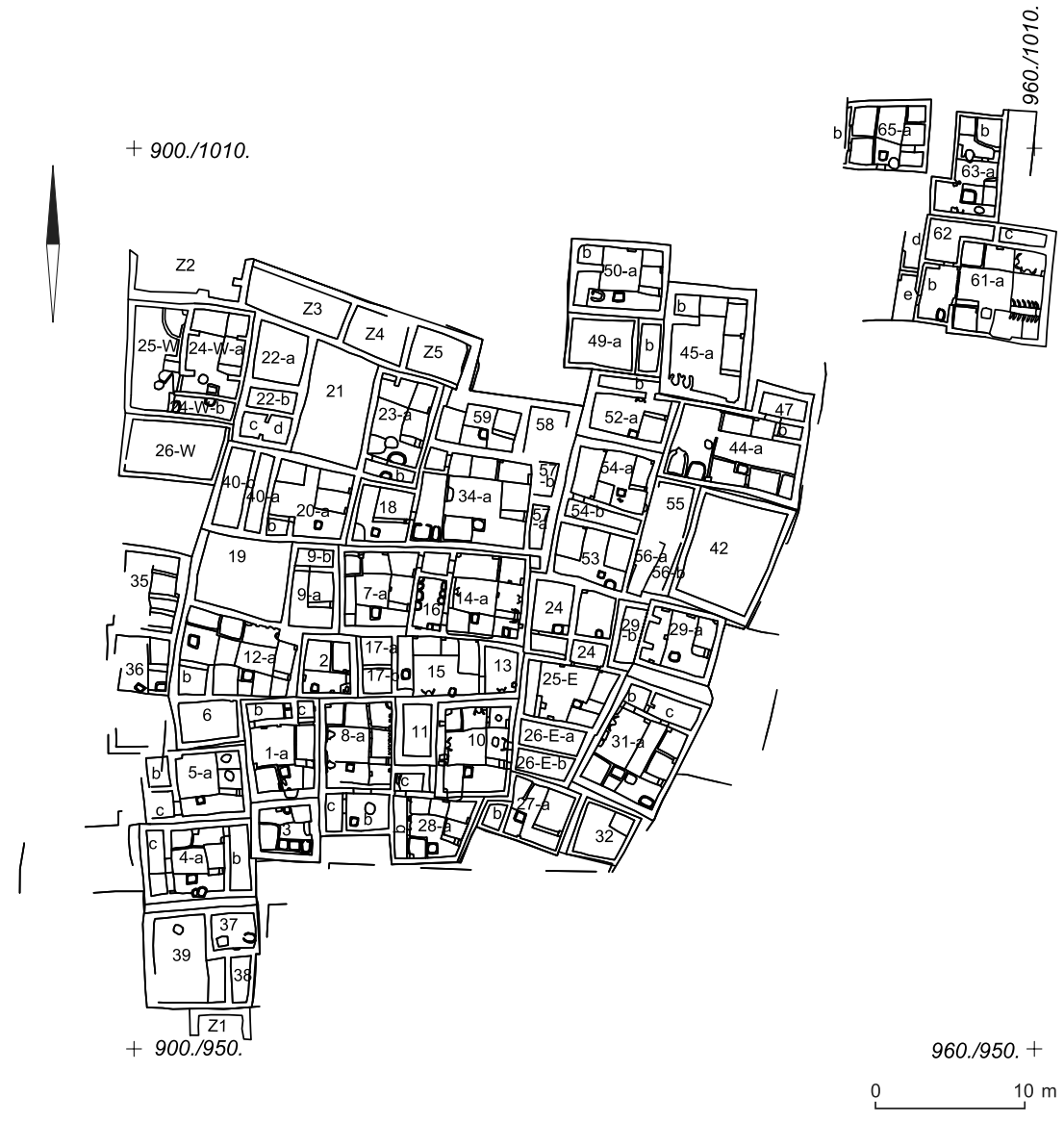

Figure 5 Plan of Çatalhöyük level VIB as excavated in the 1960s. Based on figure 2 in Mellaart (1964). Figure prepared by M. Oberendorff.

In terms of size, these living rooms at Çatalhöyük are much larger than the rooms of Aşıklı Höyük, averaging about $21 \mathrm{~m}^{2}$ (see figure 6), ${ }^{2}$ giving additional support for the idea that discrete households were present at this site but were lacking at Aşıklı Höyük.

In most cases the living rooms at Çatalhöyük are surrounded by their own set of outer walls, and in many cases smaller, subsidiary ante-rooms are attached to the main room, often with storage facilities, in the form of bins, contained within them. This evidence suggests that, contrary to the situation at Aşıklı Höyük, households at Çatalhöyük were clearly bounded homologous entities residing in discrete buildings with evidence for most domestic and some craft activities being performed within the residence. Thus households at Çatalhöyük seem to be autonomous and modular entities based on both co-residence in discrete houses and economic pooling occurring in these buildings, and it is possible to subdivide the clustered neighbourhoods into their constituent households. 


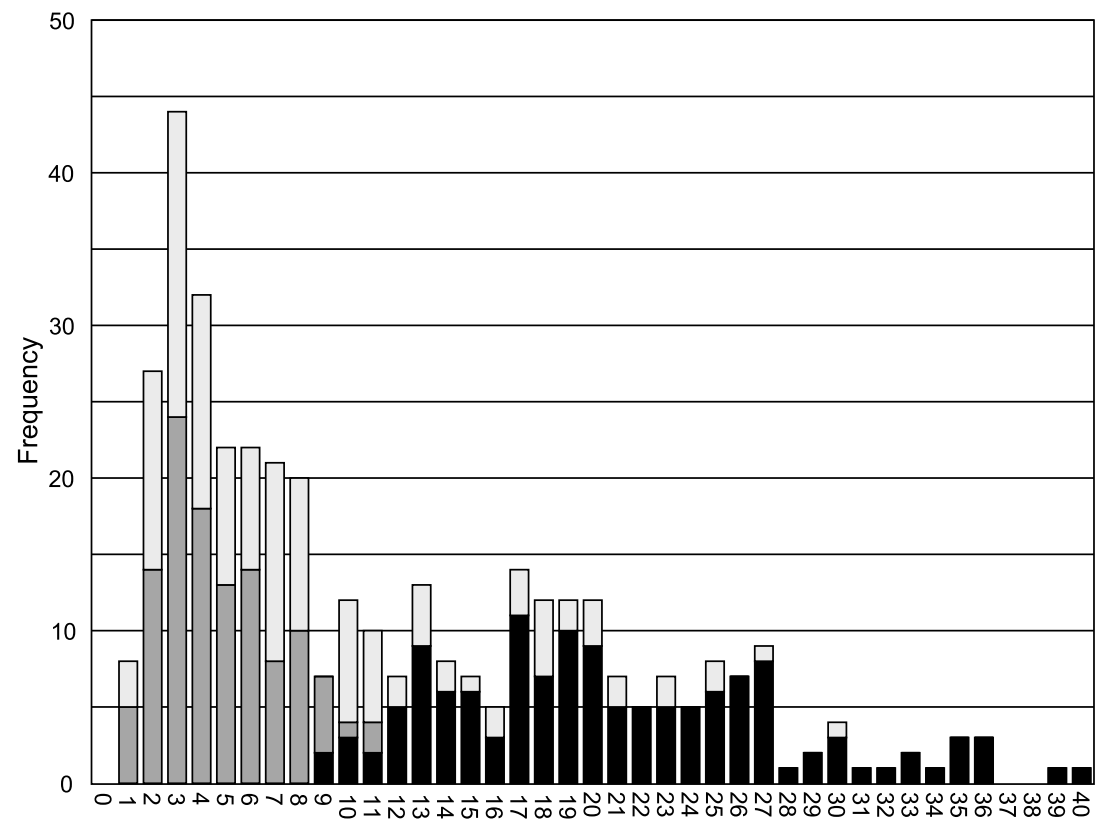

living room (mean $20.9 \mathrm{~m} 2)$

ante room (mean $4.7 \mathrm{~m} 2$ )

$\square$ indeterminate (mean $8.4 \mathrm{~m} 2$ )

Figure 6 Interior sizes of Çatalhöyük rooms in $\mathrm{m}^{2}$ by room category $(n=383)$. Figure prepared by M. Oberendorff.

However, the modular-household model runs into serious difficulties at Çatalhöyük too. First, we should ask again why people had a preference for living in clustered neighbourhoods. If households were the major social entity one would expected them to have occupied free-standing buildings, a development that occurs later in central Anatolian prehistory. We argue that the more pronounced articulation of households as bounded and autonomous entities in the early levels at Çatalhöyük was embedded in concepts of spatial organization, social interaction and ways of relating to buildings that were rooted in earlier settlement forms, one example of which is Aşıklı Höyük. While it is certainly plausible that many of the activities taking place within the Çatalhöyük buildings were centred on the individual households, there are more encompassing spheres of association as well. In a recent analysis it has been demonstrated that specific high-status buildings within the neighbourhoods were used as burial locations for a community much larger than its inhabitants (Düring 2003). The buildings in which the most substantial burial clusters were found have burial populations far exceeding the estimated number of deceased in a single household during the use-life of those buildings. This suggests that houses were differentiated in status and that there were groups of domestic buildings centred on high-status buildings in which people were preferentially buried (Düring 2005). 


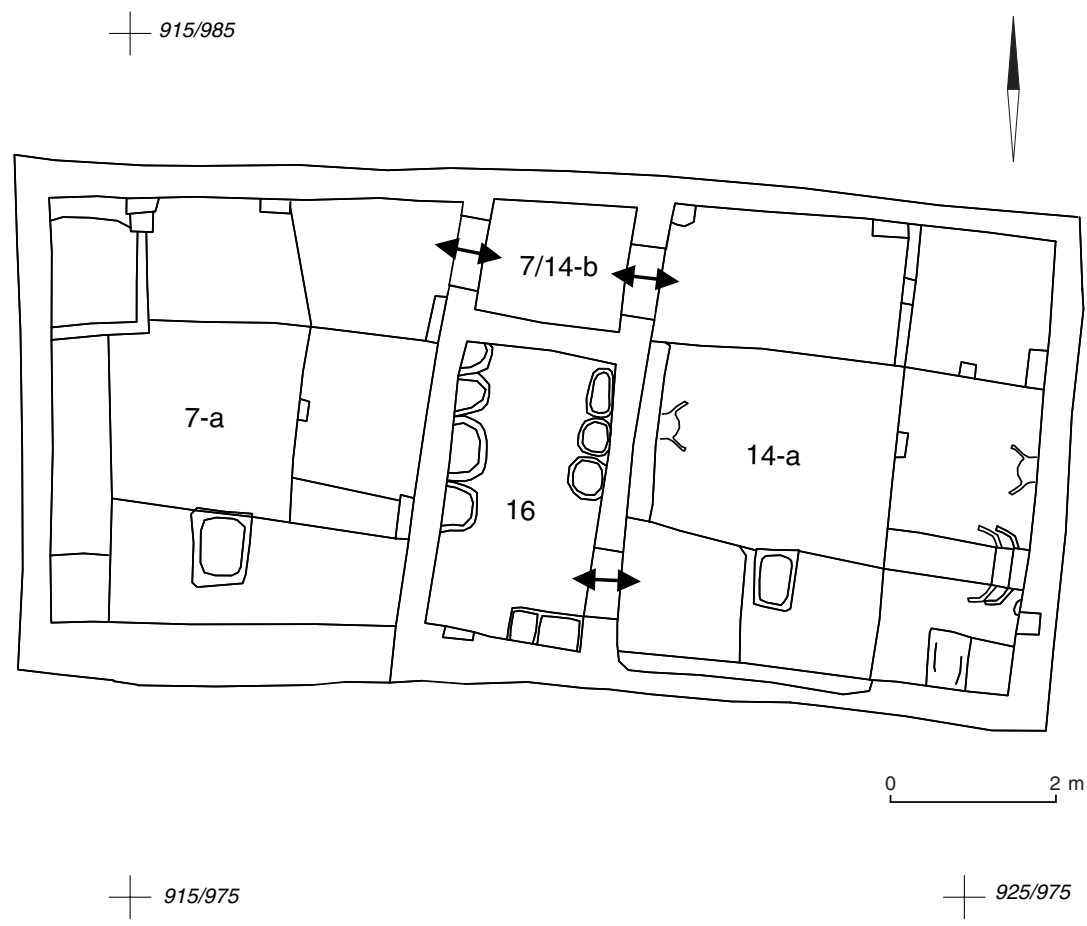

Figure 7 A level-VIB twin building at Çatalhöyük. Based on figure 1 in Mellaart (1964). Figure prepared by M. Oberendorff.

Second, buildings at Çatalhöyük, like at Aşıklı Höyük, remain remarkably similar in size and internal organization over the centuries, contrary to what one would expect if they represented the fortunes of individual competing households. This could suggest that neighbourhood communities, rather than households, owned the buildings in the clustered neighbourhoods, and that the individual buildings within the neighbourhood were distributed amongst neighbourhood residents according to their changing demands and statuses.

Third, there is good evidence at Çatalhöyük for the existence of buildings containing multiple living rooms. Most of these are in the form of 'twin buildings' in which two living rooms were in direct contact via internal doors (see figure 7). At least in these cases a special relation between the household groups in interconnected units may be presumed, and it seems difficult to think of these as discrete and autonomous households. This evidence may suggest that for people at Çatalhöyük the household was not necessarily thought of as a separate and distinct entity, although in many respects it may have functioned in that manner.

We can conclude that in the early levels X-VI at Çatalhöyük the evidence for autonomous household units is not unequivocal. Certainly households are much more bounded entities at this site than at Aşıklı Höyük, but at the same time households are subsumed in larger social associations in a variety of ways. Nonetheless, it seems clear that households played a 
much more pronounced role at Çatalhöyük than at the earlier site of Aşıklı Höyük. It is possible that at Çatalhöyük there was some tension between the neighbourhood association and the household, and this could help to explain the demise of the clustered neighbourhood at Çatalhöyük in levels V-I.

After level $\mathrm{V}$ the building continuity that had been characteristic of Çatalhöyük in the early levels seems to have been abandoned (Düring 2001; 2005). In some cases older walls were still used as a foundation, but as a rule buildings were no longer replicated after abandonment, and consequently there must have been a series of conscious decisions not to adhere to the older traditions of building continuity and to build houses in a less precedented fashion. It seems that from level $\mathrm{V}$ onwards building continuity and replacement were no longer significant in the way they had been before. It is also clear that we are not dealing with any kind of discontinuation or hiatus. This period is further marked by the appearance of exterior doorways and the emergence of courts and streets, which made the houses more accessible than had previously been the case.

Here we would like to suggest that these changes are best understood as changes in the way in which society was constituted, and that a shift took place from a situation in which households were constituent elements of the neighbourhood community to one in which households were the primary component of society. This shift can be related to other changes in the Neolithic economy and in settlement forms. Conolly (1999) has argued that lithic industries became more complex in the upper levels at Çatalhöyük and relates this to craft specialization by skilled individuals. Hamilton (1996) and Voigt (2000) have argued that gender differences became more pronounced in the figurines from level VI onwards. Concomitant with an increasing dependence on domestic food sources, male prowess in capturing wild animals seems to be depicted in the so-called hunting scenes of the upper levels at the site. Thus there seems to be some tentative evidence for the emergence of household craft specialization and a more pronounced gender differentiation in the Late Ceramic Neolithic at Çatalhöyük.

Whereas Çatalhöyük is the only settlement in the landscape surrounding the site during the Early Ceramic Neolithic, the Late Ceramic Neolithic is marked by the appearance of many smaller sites, which continue into the subsequent Early Chalcolithic (Baird 2002). At Çatalhöyük the east mound was abandoned in this period and some members of the local community probably moved to the adjacent west mound. Only the upper levels of the Early Chalcolithic sites in the Çatalhöyük region, a period which can be dated to 6000-5500 Cal. B.C., have been investigated, and consequently the transition between this period and the preceding Neolithic remains poorly known. ${ }^{3}$ What does seem to be clear from the Team Poznań excavations on the summit of Çatalhöyük East, with an occupation that dates to the end of the Late Ceramic Neolithic, is that many of the elements that are found in the Early Chalcolithic sites began at the end of Late Ceramic Neolithic sequence, making the border between these two periods blurred. Amongst the elements that appear characteristic for the Early Chalcolithic but of which the roots may lie in the preceding Neolithic period is the household as an autonomous entity (Gérard 2002). 


\section{Discussion}

The analysis of the spatial and social configurations of the Aşıklı Höyük and Çatalhöyük settlements brings up a number of issues surrounding the emergence and further development of Neolithic households and communities in central Anatolia that we want to explore in this section.

The Early Neolithic settlements in central Anatolia can be characterized as substantial agglomerations characterized by a very dense clustering of domestic buildings that were grouped in neighbourhood blocks encompassing between 30 and 40 buildings. The evidence from the earliest central Anatolian Neolithic suggests that households were not well-defined entities. At Aşıklı Höyük evidence for units occupying discrete residences in which they performed most of their domestic activities is conspicuously absent. Instead, a larger form of association, centred on the neighbourhood and probably incorporating a group of households that were spatially dispersed in the neighbourhood, seems to have been central to society at Aşıklı Höyük. This social configuration persisted during the whole sequence of the site as implied by the lack of changes in house layout and in the spatial arrangement of the settlement. The neighbourhood groups were a constituent part of the larger local community inhabiting the settlement. The communal component of society at Aşıklı Höyük is manifested in the large and monumental structure surrounding court HV.

In the early levels X-VI of Çatalhöyük the neighbourhood community continued to be a significant organizing principle of society, as indicated by the salience of the clustered neighbourhoods and by the asymmetric distribution of sub-floor burials over the houses. Some buildings clearly served as burial sites for groups larger than their inhabitants. Further, the fact that individual buildings were not significantly altered throughout a sequence of reconstructions that in many cases lasted several centuries may suggest that individual houses were distributed amongst the members of the neighbourhood communities rather than owned by specific households. However, in contrast to Aşıklı Höyük, there is good evidence for well-defined homologous households constituted on the basis of both co-residence and economic pooling at Çatalhöyük; these households occupied discrete buildings with a standardized set of features and were integrated with domestic activities, and that they were integrated into larger neighbourhood associations.

In the final occupation phases (levels V-I) at Çatalhöyük, the clustered neighbourhoods were in the process of disintegration and were finally abandoned. This process is probably related to the more pronounced role of increasingly autonomous households in the constitution of society at the expense of the neighbourhood community. Thus it is only after about two millennia of the Neolithic in central Anatolia, in which the larger neighbourhood community dominated society, that the household became the paramount form of social association.

The emergence of the autonomous household produced a new situation for two reasons: first, it formed a new social arena for negotiation, discussion and resistance, thus creating a significant social entity per se; second, it led to the creation of new relations amongst households involving tension, negotiation and conflict. In the long run, the central Anatolian Neolithic house may have 
been transformed from a communal domain into a private sphere in the Chalcolithic (see also Stea and Turan 1993, 110). This transformation may have contributed to more efficient economic activities occurring in the context of the household.

The social transformations of Neolithic communities in central Anatolia need to be seen as the outcome of a local trajectory, albeit set within the wider context of the Near East. In the initial central Anatolian Neolithic, settlements composed of neighbourhood clusters acted as the basic constituent elements of society, creating clearly bounded neighbourhood groups and local communities. Later, the configuration of older and further recontextualized settlement forms provided the conceptual framework for the changing constitution of communities. The meaning of settlements and their constituent neighbourhoods in the course of time often became self-evident and derived primarily from people's experiences related to their use. In the course of this process referential meaning was replaced by experiential meaning (see e.g. Hodder 1997). Over time settlement mounds became cultural landmarks and depositories of memory and the focal locales of communal identity (Akkermans and Schwartz 2003, 97). Large settlements such as Aşılılı Höyük and Çatalhöyük, originally located in relatively empty landscapes (Baird 2002), became significant points of reference for emerging and forming local communities at the regional scale.

Autonomous households initially developed in the central Anatolian Neolithic as a component element of the Early Neolithic neighbourhood clusters and eventually contributed to their demise. The gradual increase in household autonomy challenged the social, ceremonial and economic foundations of the neighbourhood communities. The emergence of the autonomous household marked and brought about considerable changes in the social and economic existence of the Neolithic farmers. It became an important vehicle for transformations in the context of the central Anatolian Neolithic, and eventually led to considerable changes in the configuration of local communities. Thus the household was the very social arena in which the transformation and modification of various domains took place.

\section{Conclusions}

The paper has discussed changes in the settlement forms and social configurations of the central Anatolian Neolithic. In particular, it challenges the dominant view of Neolithic societies in central Anatolia as being constituted by autonomous and homologous households, and draws attention to the transformations of household forms in this horizon and how they were related to other levels of social association.

With these considerations in mind we have discussed the evidence from the central Anatolian Neolithic sites of Aşıklı Höyük and Çatalhöyük in order to demonstrate that at least in this region the predominant social structure was not that of autonomous households, and that due consideration should be given to other forms of social association, in this case the clustered neighbourhood.

At Aşıklı Höyük households seem to be subsumed in the neighbourhood clusters, given that no discrete household residences in which domestic 
activities were performed can be discerned. Further, such a model accounts better for the fact that buildings are clustered in neighbourhoods. Instead, a larger form of social association, centred on the neighbourhood and incorporating a group of households, seems to have been central to society at Aşıklı Höyük.

At Çatalhöyük the picture is somewhat different. Here too we have neighbourhood clusters in the early levels at the site $(\mathrm{X}-\mathrm{VI})$, but we can also identify more or less discrete household residences in which a standardized set of features associated with domestic activities were found. However, the fact that buildings are clustered in neighbourhoods, and the differential distribution of burials in these neighbourhoods, with some buildings serving as burial sites for groups larger than their inhabitants, strongly suggest that at Çatalhöyük, too, the neighbourhood community was of great importance. Finally, the evidence for twin buildings - buildings with two living rooms suggests that individual households may not in all cases have been conceptualized as discrete entities.

It is in the upper levels at Çatalhöyük (V-I) that the neighbourhood community breaks up, and most buildings are now accessible directly from open spaces. This shift in the spatial organization of the settlement might well mark the appearance of more autonomous households. Thus it is only after about two millennia of the Neolithic in central Anatolia, in which the larger neighbourhood community dominated society, that the autonomous household became the paramount form of social association.

This development can only be understood in relation to the local culturehistorical trajectory of development, which is revealed to us through a number of relatively well-investigated, but not necessarily representative, settlements that were part of an overlapping cultural horizon. Accordingly, attempts to synthesize the Neolithic as a whole, as conducted by Hodder (1990) and Cauvin (1997), seem intrinsically and unjustifiably totalizing and overly simplistic to us. We would argue that the Near Eastern Neolithic should better be perceived as fragmented and as a mosaic (Tringham 2000).

All this does not imply that the domestic sphere of life was not a pivotal component of Early Neolithic society. Instead, we would like to suggest that this domain could take on many forms and configurations within society at large during the Neolithic. We believe that this variability in social forms deserves further exploration, and this paper, we hope, has indicated the potential for such studies.

\section{Acknowledgements}

This paper is based on papers presented by Bleda Düring and Arkadiusz Marciniak (written with Lech Czerniak) at the EAA conference in Lyon, September 2004, in the session 'Landscape, settlements and artefacts. New developments in Neolithic and Chalcolithic Anatolia and the Balkans'. We would like to thank the organizers of the above session and the audience at that session for providing an initial platform for formulating our ideas. Further, we would like to thank Ian Hodder and the Çatalhöyük Project for creating a wonderful environment in which our research can flourish. Bleda Düring would like to thank the Faculty of Archaeology for funding his Ph.D. 
research, of which this article is part. Arkadiusz Marciniak would like to thank Lech Czerniak for numerous discussions and inspirations. A draft of this paper was read and commented upon by John Bintliff, for which we are grateful. The figures were prepared by Medy Oberendorff and we would like to thank her. Finally, we thank the anonymous reviewers and the editors of Archaeological dialogues for comments that helped improve this paper.

\section{Notes}

${ }^{1}$ In this discussion we focus on what we perceive to be the dominant reconstruction of Neolithic societies in the Levant. An alternative model can be found in the work of Kuijt (2000, 140-41), but that falls outside the scope of this brief discussion.

2 The Çatalhöyük buildings remain similar in size throughout the Early Ceramic Neolithic (levels X-I), and in this respect no differentiation can be made between the early levels $\mathrm{X}-\mathrm{VI}$ and the later levels V-I.

${ }^{3}$ Likewise the exposures of levels $7-4$ at Canhasan I are very restricted in size, and do not much help us understand this transition (see French 1998).

\section{References}

Acar, E., 2001: From hut to citadel. The evolution of housing and settlement in Prehistoric Anatolia as changing patterns of space and time, in J.R. Brandt and L. Karlsson (eds), From huts to houses. Transformations of ancient societies, Stockholm, 11-21.

Akkermans, P.M.M.G., and G.M. Schwartz, 2003: The archaeology of Syria. From complex hunter-gatherers to early urban societies, Cambridge.

Allison, P.M., 1999: Introduction, in P.M. Allison (ed.), The archaeology of households, London, 1-18.

Ashmore, W., and R.R. Wilk, 1988: Household and community in the Mesoamerican past, in R.R. Wilk and W. Ashmore (eds), Household and community in the Mesoamerican past, Albuquerque, 1-27.

Baird, D., 2002: Early Holocene settlement in Central Anatolia. Problems and prospects as seen from the Konya Plain, in F. Gérard and L. Thissen (eds), The Neolithic of Central Anatolia. Internal developments and external relations during the 9th-6th millennia cal. BC, Istanbul, 139-59.

Balkan-Atlı, N., and D. Binder, 2001: Les ateliers de taille d'obsidienne. Fouilles de Kömürcü-Kaletepe 2000, Anatolia antiqua 9, 193-205.

Banning, E.B., 2003: Housing Neolithic farmers, Near Eastern archaeology 66, 4-21.

Blanton, R.E., 1994: Houses and households. A comparative study, New York.

Byrd, B.F., 1994: Public and private, domestic and corporate. The emergence of the Southwest Asian village, American antiquity 59, 639-66.

Byrd, B.F., 2000: Households in transition. Neolithic social organization within Southwest Asia, in I. Kuijt (ed.), Life in Neolithic farming communities. Social organization, identity, and differentiation, New York, 63-98.

Casselberry, S.E., 1974: Further refinement of formulae for determining population from floor area, World archaeology 6, 116-22.

Cauvin, J., 1997 [1994]: Naissance des divinités. Naissance de l'agriculture, Paris.

Cessford, C., 2001: A new dating for Çatalhöyük, Antiquity 75, 717-25. 
Colledge, S., J. Conolly and S. Shennan, 2004: Archaeobotanical evidence for the spread of farming in the Eastern Mediterranean, Current anthropology 45 (Supplement), 35-58.

Conolly, J., 1999: Technical strategies and technical change at Neolithic Çatalhöyük, Turkey, Antiquity 73, 791-800.

Cook, S.F., and R.F. Heizer, 1968: Relationship among houses, settlement areas, and population in Aboriginal California, in K.C. Chang (ed.), Settlement archaeology, Palo Alto, 79-116.

Czerniak, L., and A. Marciniak, 2004: New perspectives on the transition between Neolithic and Chalcolithic in Central Anatolia. Paper presented at the 10th Meeting of the European Association of Archaeologists, Lyon.

Dohm, K., 1990: Effects of population nucleation on house size for Pueblos in the American Southwest, Journal of anthropological archaeology 9, 201-39.

Düring, B.S., 2001: Social dimensions in the architecture of Neolithic Çatalhöyük, Anatolian studies 51, 1-18.

Düring, B.S., 2002: Cultural dynamics of the Central Anatolian Neolithic. The Early Ceramic Neolithic-Late Ceramic Neolithic transition, in F. Gérard and L. Thissen (eds), The Neolithic of Central Anatolia. Internal developments and external relations during the 9th-6th millennia cal. BC, Istanbul, 219-36.

Düring, B.S., 2003: Burials in context. The 1960s inhumations of Çatalhöyük East, Anatolian studies 53, 1-15.

Düring, B.S., 2005: Building continuity in the Central Anatolian Neolithic. Exploring the meaning of buildings at Aşıklı Höyük and Çatalhöyük, Journal for Mediterranean archaeology 18, 1-20.

Esin, U., 1996: Aşıklı ten thousand years ago. A habitation model from Central Anatolia, in Y. Sey Hacilar (ed.), Housing and settlement in Anatolia. A historical perspective, Istanbul, 31-42.

Esin, U., 1998: The Aceramic site of Aşıklı and its ecological conditions based on its floral and faunal remains, Türkiye Bilimler Akademisi Arkeoloji Dergisi 1, 63-94.

Esin, U., E. Bıçakçı, M. Özbaşaran, N. Balkan-Atlı, D. Berker, I. Yağmur and A. Korkut-Ali, 1991: Salvage excavations at the pre-pottery Neolithic site of Aşıklı Höyük in Central Anatolia, Anatolica 17, 123-74.

Esin, U., and S. Harmankaya, 1999: Aşıklı, in M. Özdoğan and N. Başgelen (eds), The Neolithic of Turkey, Istanbul, 115-32.

Farid, S., forthcoming: South Area excavations, in I. Hodder (ed.), Excavating Çatalhöyük. South, north and KOPAL area reports from the 1995-1999 seasons, Cambridge.

Flannery, K.V., 1972: The origins of the village as a settlement type in Mesoamerica and the Near East. A comparative study, in R. Tringham, P.J. Ucko and G.W. Dimbledy (eds), Man, settlement and urbanism, Gloucester, 23-53.

Flannery, K.V., 2002: The origins of the village revisited. From nuclear to extended households, American antiquity 67, 417-33.

French, D., 1998: Canhasan sites I. Stratigraphy and structures, Ankara.

Geertz, H., 1979: The meaning of family ties, in C. Geertz, H. Geertz and L. Rosen, Meaning and order in Moroccan society. Three essays in cultural analysis, Cambridge, 315-79.

Gérard, F., 2002: Transformations and societies in the Neolithic of Central Anatolia, in F. Gérard and L. Thissen (eds), The Neolithic of Central 
Anatolia. Internal developments and external relations during the 9th-6th millennia cal. BC., Istanbul, 105-17.

Gérard, F., and L. Thissen (eds), 2002: The Neolithic of Central Anatolia. Internal developments and external relations during the 9th-6th millennia cal. $B C$, Istanbul.

Hamilton, N., 1996: Figurines, clay balls, small finds and burials, in I. Hodder (ed.), On the surface. Çatalhöyük 1993-5, Cambridge, 215-64.

Hendon, J.A., 1996: Archaeological approaches to the organization of domestic labor. Household practice and domestic relations, Annual review of anthropology 25, 45-61.

Hodder, I., 1990: The domestication of Europe. Structure and contingency in Neolithic societies, Oxford.

Hodder, I., 1996: Çatalhöyük, 9000 year old housing and settlement in Central Anatolia, in Y. Sey (ed.), Housing and settlement in Anatolia. A historical perspective, Istanbul, 43-48.

Hodder, I., 1997: Architecture and meaning. The example of Neolithic houses and tombs, in M.P. Pearson and C. Richards (eds), Architecture and order. Approaches to social space, London, 73-86.

Hodder, I., 1998: The domus. Some problems reconsidered, in M. Edmonds and C. Richards (eds), Understanding the Neolithic of Northwestern Europe, Glasgow, 84-101.

Hodder, I., 2005: Peopling Çatalhöyük and its landscape, in I. Hodder (ed.), Inhabiting Çatalhöyük. Reports from the 1995-1999 seasons, Cambridge, $1-30$.

Hodder, I. and C. Cessford, 2004: Daily practice and social memory at Çatalhöyük, American antiquity 69, 17-40.

Hole, F., 2000: Is size important? Function and hierarchy in Neolithic settlements, in I. Kuijt (ed.), Life in Neolithic farming communities. Social organization, identity, and differentiation, New York, 191-209.

Horne, L., 1994: Village spaces. Settlement and society in northeastern Iran, Washington.

Kovacik, J.J., 2002: Radical agency, households and, communities. Networks of power, in M. O'Donovan (ed.), The dynamics of power, Carbondale, $51-65$.

Kuijt, I., 2000: Keeping the peace. Ritual, skull caching, and community integration in the Levantine Neolithic, in I. Kuijt (ed.), Life in Neolithic farming communities. Social organization, identity, and differentiation, New York, 137-64.

Lane, P.J., 1994: The temporal structuring of settlement space among the Dogon of Mali. An ethnoarchaeological study, in M.P. Pearson and C. Richards (eds), Architecture and order. Approaches to social space, London, 196-216.

Last, J., 1996: Surface pottery at Çatalhöyük, in I. Hodder (ed.), On the surface. Çatalhöyük 1993-5, Cambridge, 115-72.

Mellaart, J., 1963: Excavations at Çatal Hüyük. Second preliminary report, 1962, Anatolian studies 13, 43-103.

Mellaart, J., 1964: Excavations at Çatal Hüyük. Third preliminary report, 1963, Anatolian studies 14, 39-119.

Mellaart, J., 1966: Excavations at Çatal Hüyük. Fourth preliminary report, 1965, Anatolian studies 16, 165-91.

Mellaart, J., 1967: Çatal Hüyük. A Neolithic town in Anatolia, London. 
Naroll, R., 1962: Floor area and settlement population, American antiquity 27, 587-89.

Netting, R.McC., 1990: Population, permanent agriculture, and polities. Unpacking the evolutionairy portmanteau, in S. Upham (ed.), The evolution of political systems. Sociopolitics in small-scale sedentary societies, Cambridge, 21-61.

Özbaşaran, M., 1998: The heart of a house, the hearth, in M.J. Mellink, G. Arsebük and W. Schirmer (eds), Light on top of the black hill. Studies presented to Halet Çambel, Istanbul, 555-66.

Özbaşaran, M., 2000: The Neolithic site of Musular, Central Anatolia, Anatolica 26, 129-51.

Özdoğan, M., 1999: Concluding remarks, in M. Özdoğan and N. Başgelen (eds), The Neolithic of Turkey, Istanbul, 225-36.

Robin, C., 2003: New directions in Classic Maya household archaeology. Journal of archaeological research 11, 307-36.

Spencer-Wood, S.M., 1999: The world their household. Changing meanings of the domestic sphere in the nineteenth century, in P.M. Allison (ed.), The archaeology of household activities, London, 162-89.

Stea, D., and M. Turan, 1993: Placemaking. Production of built environment in two cultures, Aldershot.

Steadman, S.R., 2000: Spatial patterning and social complexity on Prehistoric Anatolian tell Sites. Models for mounds, Journal of anthropological archaeology 19, 164-99.

Todd, I.A., 1976: Çatal Hüyük in perspective, Menlo Park.

Tringham, R., 2000: Southeastern Europe in the transition to agriculture in Europe. Bridge, buffer or mosaic?, in T.D. Price (ed.), Europe's first farmers, Cambridge, 19-56.

Voigt, M.M., 2000: Çatal Hüyük in context. Ritual at Early Neolithic sites in Central and Eastern Turkey, in I. Kuijt (ed.), Life in Neolithic farming communities. Social organization, identity, and differentiation, New York, 253-93.

Watkins, T., 2001: Re-thinking the Neolithic revolution and its consequences, in C. Breniquet and C. Kepinski (eds), Études mésopotamiennes. Recueil de textes offert à Jean-Louis Huot, Paris, 489-507.

Wilk, R.R., and W.L. Rathje, 1982: Household archaeology, American behavioral scientist 25, 617-39.

Yakar, J., 1991: Prehistoric Anatolia. The Neolithic transformation and the Early Chalcolithic period, Tel Aviv. 